\title{
Mobilność w optyce młodych osób - na przykładzie Polski i Portugalii ${ }^{1}$
}

\author{
IZABELA BEDNARSKA-WNUK
}

Katedra Zarządzania, Wydział Zarządzania, Uniwersytet Łódzki

\begin{abstract}
Skutki kryzysu finansowego z 2008 roku sprawiły, że wiele krajów - także tych z obszaru Unii Europejskiej - boryka się z niekorzystnymi trendami na rynkach pracy. Jego asymetria sprawia, że coraz więcej osób jest bezrobotnych zwłaszcza w przedziale poniżej 25 roku życia. Są to osoby przede wszystkim bardzo dobrze wykształcone, posiadające wysokie umiejętności i kwalifikacje. W związku z tą sytuacją wiele młodych osób podejmuje decyzję o zmianie miejsca zamieszkania bądź zawodu w celu lepszego dopasowania się do rynku pracy. Celem artykułu jest identyfikacja stopnia akceptacji skłonności młodych osób do mobilności zawodowej i przestrzennej. Dokonano również porównania wybranych czynników zawodowych w ich przyszłej pracy na przykładzie dwóch krajów: Polski i Portugalii.
\end{abstract}

Słowa kluczowe: mobilność, pokolenie Y, rynek pracy, Polska, Portugalia.

\section{Wprowadzenie}

W wyniku dokonujących się zmian w gospodarce, coraz częściej podejmuje się dyskusję na temat funkcjonowania człowieka na współczesnym rynku pracy. Zachodzą na nim dynamiczne zjawiska, związane z takimi kategoriami makroekonomicznymi, jak: bezrobocie, inflacja czy wartość produktu krajowego brutto. Wszystko to sprawia, że rynek pracy jest bardzo heterogeniczny, a popyt na pracę przewyższa jej podaż. Sytuacja ta dotyczy prawie całej Unii Europejskiej, która obecnie zmaga się z niekorzystnymi trendami demograficznymi i społecznymi

1 Artykuł powstał w ramach projektu „Indywidualne i organizacyjne determinanty mobilności pracowników" Nr 545/319 (2012) - Dotacja celowa dla młodych naukowców, Kierownik Projektu dr Izabela Bednarska-Wnuk. 
oraz zmianami na rynkach finansowych. Niektóre zaś kraje, takie jak Hiszpania, Portugalia czy Grecja odczuwają wziąż jeszcze skutki kryzysu gospodarczego z 2008 roku. Również do tych krajów coraz częściej dołączają nowe, które jeszcze niedawno były podawane jako przykład radzenia sobie z kryzysem gospodarczym. Takim krajem jest właśnie Polska, która w czasie kryzysu odnotowywała wzrost gospodarczy, a obecnie ma do czynienia ze spowolnieniem gospodarczym.

Również zwiększający się odsetek osób bezrobotnych sprawia, że coraz trudniej jest się odnaleźć na rynku pracodawcy, na którym podaż wolnych zasobów pracy jest bardzo duża. Sytuacja ta jest szczególnie trudna wśród osób młodych, próbujących dopiero zaistnieć na tym rynku. Wiele z tych osób ukończyło studia, posiada dodatkowe kwalifikacje i umiejętności. Czy zatem osoby te mają szansę stać się częścią coraz to bardziej „kurczącego” się rynku pracy? Wymaga to od nich podejmowania zachowań mobilnych, które są coraz częściej analizowane zarówno w teorii jak i praktyce zarządzania (Kronenberg, Carree 2012; Ng i inni, 2007). Młode osoby zaczynają zdawać sobie sprawę, że współcześnie aby sprostać wymaganiom współczesnego rynku pracy należy charakteryzować się działaniami mobilnymi. Biorąc pod uwagę powyższe rozważania celem artykułu była identyfikacja stopnia akceptacji skłonności młodych osób do mobilności zawodowej i przestrzennej oraz przeprowadzenie porównania wybranych czynników zawodowych w ich przyszłej pracy na przykładzie dwóch krajów: Polski i Portugalii. Kraje te wybrano celowo, ze względu na różny staż w Unii Europejskiej, położenie geograficzne, kulturę, a przede wszystkim zróżnicowane wskaźniki makroekonomiczne.

\section{Mobilność - podstawy teoretyczne}

Mobilność w literaturze utożsamiana jest najczęściej z ruchliwością społeczną (Sorokin, 2009) i procesami związanymi z employability (Houston, 2005). W jej obszarze można natomiast wyodrębnić wiele podziałów. Najczęstszy z nich dzieli mobilność dwa główne typy: poziomą (horyzontalną) i pionową (wertykalną) (Sorokin, 2009, s. 132). Oprócz tego można jeszcze wyszczególnić inne podziały oparte na różnych kryteriach. Dla przykładu N. Nicholson i M. West wyróżnili dwanaście rodzajów mobilności zawodowej w oparciu o trzy wymiary: status (w górę, w dół, boczny), funkcja (ta sama, zmienna) i charakter pracodawcy (wewnętrzny, zewnętrzny) (Nicholson, West, 1988). Z kolei na podstawie tej typologii T. Ng, K.L. Sorensen, L.T. Eby, D.C. Feldman skupiając się wyłącznie na wymiarze statusu i rodzaju pracodawcy opracowali sześć podstawowych rodzajów mobilności (Ng i inni, 2007). Nie negując różnych typów i klasyfikacji mobilności w kontekście funkcjonowania rynku pracy i postaw pracowników można wyodrębnić dwa 
podstawowe rodzaje mobilności: mobilność przestrzenną i zawodową ${ }^{2}$. Pierwsza $\mathrm{z}$ nich przestrzenna związana jest $\mathrm{z}$ przemieszczeniem się jednostki $\mathrm{w}$ celu poszukiwania pracy lub z dojazdami do pracy, wewnątrz kraju i poza nim. Natomiast mobilność zawodowa obejmuje skłonność pracowników do zmiany pracodawcy, kwalifikacji lub statusu zawodowego jednostki, przy czym w jej obrębie można zidentyfikować: wewnętrzną mobilność zawodową związaną ze zmianami w ramach obecnego miejsca pracy oraz zewnętrzną mobilność zawodową związaną z przemieszczeniami pomiędzy zawodami a pracodawcami (Sienkiewicz, 2009, s. 69).

Mobilność jest pojęciem złożonym i wielowymiarowym. Jest również ważnym zagadnieniem w kontekście modelowania postaw osób młodych. To, w jakim stopniu będą przejawiać oni skłonność do mobilności (przestrzennej i zawodowej), będzie miało wpływ na ich odnalezienie się na współczesnym rynku pracy. Postawy mobilne młodych osób powinny być zatem kształtowane w taki sposób, aby mogły wpisywać się w ich atrakcyjność zatrudnieniową. W tej sytuacji wydaje się, że takie postawy powinny być również promowane przez systemy edukacyjne, organizacje czy państwo - jako wspierające działania każdego społeczeństwa.

\section{Polski a portugalski rynek pracy - analiza porównawcza}

Rynek pracy jest źródłem informacji, na podstawie której państwo może stosować różne instrumenty polityki makroekonomicznej. W wyniku ogólnoświatowego kryzysu gospodarczego, rozpoczętego w 2007 roku w Stanach Zjednoczonych gospodarki wielu krajów znalazły się na krawędzi bankructwa. Do głównych przyczyn tego kryzysu zaliczono: globalną nierównowagę finansową, niewłaściwe funkcjonowanie niektórych rynków oraz nieadekwatną politykę pieniężną amerykańskiej Rezerwy Federalnej (Fed) w latach poprzedzających kryzys (Samecki, 2011, s. 9). Globalny kryzys nie ominął również krajów Unii Europejskiej i jej rynków finansowych. Dotknął on głównie państwa, takie jak: Grecja, Portugalia, Hiszpania, Irlandia, Włochy czy Francja (Guillén, 2012). Natomiast z punktu widzenia badania postaw młodych osób zainteresowanych krajami, uwagę skupiają te, które charakteryzują się różnicami kulturowymi, zróżnicowanym poziomem gospodarczym i różnym stażem funkcjonowania w Unii Europejskiej. Takimi krajami są Portugalia i Polska. Pierwszy z nich, Portugalia to kraj, który już w 1986 roku wstąpił do Unii Europejskiej. W tym okresie produkt krajowy brutto per capita jak podają Dimian G. i Dimian M. (na podstawie danych uzyskanych z World Bank

\footnotetext{
2 Szerzej na temat rodzajów i determinant mobilności w: Bednarska-Wnuk (2013, s. 43-51).
} 
i World Development Indicators \& Global Development Finance) był niewiele wyższy niż 50\% od średniej innych państw członkowskich. Jednakże już w 1987 roku Portugalia odnotowała wzrost tego produktu aż o 6,5\% (Dimian, Dimian, 2011, s. 285). Po okresie znacznego rozwoju tego państwa pod koniec lat 90., stopa wzrostu gospodarczego utrzymywała się powyżej średniego poziomu dla krajów Unii Europejskiej. W 2003 roku trend wzrostowy został zahamowany, a znaczącą różnicę można było zauważyć w 2007 roku, w którym to PKB wzrósł o 1,9\%. Natomiast w wyniku ogólnoświatowego kryzysu tempo wzrostu gospodarczego w Portugalii w 2008 roku znacznie się obniżyło, a już w 2009 roku spadł do poziomu 2,9\%. Kryzys spowodował zamknięcie wielu przedsiębiorstw i wzrost bezrobocia (Dias, Conceição Cerdeira, 2011, s. 406). Obecnie w Portugalii rynek pracy kurczy się nieprzerwanie od 5 lat, a w szczególności od momentu podpisania „paktu fiskalnego”, opracowanego przez Międzynarodowy Fundusz Walutowy, Komisję Europejską oraz Europejski Bank Centralny. Wymaga on bowiem od wszystkich krajów Unii Europejskiej przede wszystkim utrzymania deficytu budżetowego poniżej 3\% PKB, redukcji długu publicznego poniżej $60 \%$ PKB oraz realizacji restrykcyjnego planu antykryzysowego. W tej sytuacji nieuchronne i katastrofalne skutki na rynku pracy są łatwe do przewidzenia - państwo dąży do ograniczenia wydatków publicznych, kosztem pracowników - zamrażając bądź redukując wydatki socjalne, zmniejszając zatrudnienie czy dokonując cięć płac (Costa, 2012, s. 398). Jak podaje Instituto Nacional de Estatística w Portugalii stopa bezrobocia w III kwartale 2013 roku osiągnęła 15,5\%. Szczególna sytuacja dotyczy osób młodych i to nie tylko w Portugalii, ale w całej Unii Europejskiej (tabela 1).

W przeciwieństwie do Portugalii, w Polsce dopiero od 1989 roku problemy rynku pracy i zjawisko bezrobocia stały się obiektem zainteresowania na gruncie teoretycznym i praktycznym. Związane one były z przejściem od gospodarski centralnie planowanej do gospodarki kapitalistycznej. W poprzednim systemie (gospodarka socjalistyczna), państwo odgórnie zapewniało miejsca pracy bez względu na ich zapotrzebowanie. Bezrobocie było ukryte, a prawie wszystkie sektory gospodarki charakteryzowały się nadmiernym zatrudnieniem. Świadczą o tym dane Głównego Urzędu Statystycznego, który bezrobocie jako kategorii makroekonomicznej nie wykazywał w oficjalnych statystykach. W latach 90. na arenie Polski dokonały się przemiany makroekonomiczne. Jak podaje Główny Urząd Statystyczny do roku 1993 liczba osób pracujących w Polsce dramatycznie się zmniejszyła. Było to wynikiem likwidacji ukrytego bezrobocia w przedsiębiorstwach, jak i spadku ogólnej koniunktury. W latach 1994-1997 wysoki wzrost PKB (odpowiednio 5\%, 6,9\%, $5,9 \%$ oraz $6,7 \%$ ), pozwolił na wzrost zatrudnienia w gospodarce i spadek stopy bezrobocia w stosunku do 1993 roku (Kryńska, 2001, s.163). Natomiast od 1998 roku do 2003 roku stopa bezrobocia gwałtownie wzrosła z 10,4\% do $20 \%$. 
W 2004 roku Polska wstąpiła do Unii Europejskiej, co znaczenie ułatwiło Polakom podejmowanie pracy w innych krajach europejskich (Irlandia, Szwecja czy Wielka Brytania) i zapoczątkowało masową emigrację w celu poszukiwania pracy. W efekcie okazało się, że są oni bardzo mobilni (Głodowska, 2011). Wskaźniki makroekonomiczne zaczęły się poprawiać. Wzrost realny produktu krajowego brutto w 2004 roku, w porównaniu z 2003 rokiem wyniósł 5,4\% (w cenach stałych roku poprzedniego). W 2008 roku kiedy kryzys finansowy „rozprzestrzenił się" wśród krajów europejskich, w Polsce skutki tego kryzysu były odczuwalne w zdecydowanie mniejszym stopniu niż w innych krajach (Guyader 2012, s. 143). Należy przy tym dodać, że Polska była jedynym krajem w Unii Europejskiej, która w tym okresie odnotowała wzrost wartości PKB. Na ten wzrost pozytywny wpływ miał zwiększony eksport netto oraz spożycie ogółem, dobre wykorzystanie funduszy unijnych i realizowane inwestycje związane ze zbliżającym się EURO 2012. Jak wynika z danych Eurostatu w 2012 roku realne tempo wzrostu PKB w Polsce wyniosło 1,9\%. Dla porównania kraje Unii Europejskiej odnotowały wówczas spadek (-0,3\%), podobnie jak opisana wyżej Portugalia (-3,2\%). Obecnie stopa bezrobocia w Polsce jak podaje Eurostat w październiku 2013 roku wyniosła 10,2\% (UE-27 = 10,9\%). Niestety w Polsce, podobnie jak w całej Unii Europejskiej wśród osób młodych do 25 roku życia obserwuje się wzrost bezrobocia (tabela 1).

Tabela 1. Stopa bezrobocia (\%) w Polsce i w Portugalii

\begin{tabular}{|c|c|c|c|c|c|c|}
\hline & \multicolumn{2}{|c|}{ Polska } & \multicolumn{2}{|c|}{ Portugalia } & \multicolumn{2}{|c|}{$\begin{array}{c}\mathrm{UE}=25 \text { (do } 2006 \text { r.) } \\
\mathrm{UE}=27 \text { (od } 2007 \text { r.) } \\
\mathrm{UE}=28 \text { (od VII } 20013 \text { r.) }\end{array}$} \\
\hline lata & $\begin{array}{l}\text { Mniej niż } \\
25 \text { lat }\end{array}$ & Ogółem & $\begin{array}{l}\text { Mniej niż } \\
25 \text { lat }\end{array}$ & Ogółem & $\begin{array}{c}\text { Mniej niż } \\
25 \text { lat }\end{array}$ & Ogółem \\
\hline 2004 & 39,6 & 19,00 & 18,9 & 7,5 & 19,0 & 9,3 \\
\hline 2005 & 36,9 & 17,8 & 19,8 & 8,6 & 18,8 & 9,0 \\
\hline 2006 & 29,8 & 13,9 & 20,1 & 8,6 & 17,5 & 8,3 \\
\hline 2007 & 21,6 & 9,6 & 20,4 & 8,9 & 15,7 & 7,2 \\
\hline 2008 & 17,2 & 7,1 & 20,2 & 8,5 & 15,8 & 7,1 \\
\hline 2009 & 20,6 & 8,2 & 24,8 & 10,6 & 20,1 & 9,0 \\
\hline 2010 & 23,7 & 9,6 & 27,7 & 12,0 & 21,1 & 9,7 \\
\hline 2011 & 25,8 & 9,7 & 30,1 & 12,9 & 21,4 & 9,7 \\
\hline 2012 & 26,5 & 10,1 & 37,7 & 15,9 & 22,8 & 10,5 \\
\hline październik 2013 & 27,7 & 10,2 & 36,5 & 15,7 & 23,7 & 10,9 \\
\hline
\end{tabular}

Źródło: opracowanie na podstawie Eurostat 2014, http://epp.eurostat.ec.europa.eu/statistics_explained/index. php/Unemployment_and_beyond. 
Jak pokazuje powyższa tabela, jeśli 2004 rok był dla Polski okresem przełomowym (zmniejszające się bezrobocie i wzrost PKB), to w portugalskiej gospodarce zaczęły następować tendencje odwrotne. W tym miejscu należy jeszcze zaznaczyć, że bezrobocie wśród osób młodych jest zazwyczaj znacznie wyższe niż w innych grupach wiekowych. Jest to związane z tym, że nie każda $\mathrm{z}$ tych osób jest częścią siły roboczej, bowiem niektóre z nich jeszcze się uczą (studiują) i nie są zainteresowane aktualnym wejściem na rynek pracy (Eurostat, 2014).

\section{Metodyka badań}

Badaniami objęto 173 respondentów w 2012 roku, będących studentami dwóch krajów: Polski (75 osób) i Portugalii (98 osób). Grupa była homogeniczna pod względem poziomu studiów - studia I stopnia a rozkład w zależności od zmiennej płci wynosił: kobiety 63\%, mężczyźni 37\%. Zarówno w Polsce $(66,7 \%)$ jak i w Portugalii $(94,9 \%)$ badani respondenci w większości nigdzie nie pracowali i zajmowali się tylko studiowaniem. Natomiast 29,3\% studentów z Polski i tylko 4,1\% studentów z Portugalii było zatrudnionych na podstawie różnorodnych umów pracowniczych. Tylko niewielki odsetek badanych 4\% (Polska) i 1\% (Portugalia) prowadziło własną działalność gospodarczą. Badania miały charakter anonimowy i były realizowane w czasie zajęć dydaktycznych za pomocą autorskiego kwestionariusza percepcji mobilności, wykorzystującego skalę Likerta (gdzie 1-oznaczało zdecydowanie tak a 5 - zdecydowanie nie).

Celem badań była identyfikacja wybranych elementów mobilności młodych osób składających się na strukturę postaw w zakresie:

- określenia stopnia akceptacji skłonności młodych osób do mobilności zawodowej i przestrzennej,

- uchwycenia różnic pomiędzy dwoma grupami badawczymi (Polska i Portugalia) w percepcji mobilności zawodowej i przestrzennej oraz w zakresie wybranych czynników zawodowych w przyszłej pracy.

Różnice te były określane $\mathrm{z}$ wykorzystaniem nieparametrycznego testu U Manna-Whitneya (test Wilcoxona), przy poziomie istotności $\alpha=0,05$, który pozwala na porównanie dwóch niezależnych prób i nie wymaga ich równoliczności.

Ustalenia zależności pomiędzy stopniem akceptacji skłonności respondentów do mobilności, a wybranymi czynnikami zawodowymi w przyszłej pracy. Zależności te były ustalane za pomocą współczynnika korelacji Spearmana R przy zakładanym poziomie $\alpha=0,05$.

Ponieważ dobór próby był celowy i nie spełnia statystycznego wymogu reprezentatywności, dlatego uzyskany materiał badawczy pozwala jedynie na 
przedstawienie opinii na temat mobilności w percepcji wybranych młodych osób pochodzących z Polski i Portugalii. Ponadto, zamieszczone konkluzje dotyczące mobilności badanych osób ciągle jeszcze nie wykraczają poza status hipotezy, choć jest ona uprawdopodobniona poprzez uzyskane wyniki badań.

\section{Wyniki badań}

Pierwsze trzy tabele prezentują mediany i średnie rangi dla Polski i Portugalii. Uzupełnieniem ich jest zobrazowanie zbadanych różnic kulturowych między tymi krajami testem U Manna-Whitneya $(\alpha=0,05)$.

W pierwszej tabeli zamieszczono statystykę opisową dla określenia stopnia akceptacji skłonności respondentów do mobilności przestrzennej i zawodowej.

Tabela 2. Stopień akceptacji skłonności do mobilności zawodowej i przestrzennej w opinii respondentów

\begin{tabular}{|c|c|c|c|c|c|c|}
\hline & 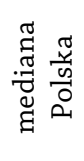 & 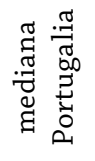 & 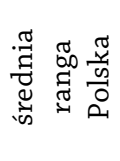 & 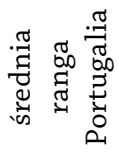 & 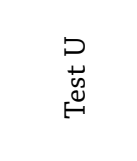 & 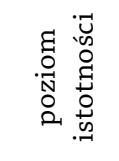 \\
\hline $\begin{array}{l}\text { skłonność do zmiany } \\
\text { kwalifikacji zawodowych }\end{array}$ & 2,0 & 2,0 & 69,4 & 100,5 & $-4,37387$ & 0,00001 \\
\hline $\begin{array}{l}\text { skłonność do poszukiwania } \\
\text { pracy na terenie innej gminy }\end{array}$ & 2,0 & 1,5 & 96,3 & 79,9 & 2,29125 & 0,02195 \\
\hline $\begin{array}{l}\text { skłonność do zmiany pracy } \\
\text { (pracodawcy) }\end{array}$ & 3,0 & 3,0 & 98,5 & 78,2 & 2,74954 & 0,00597 \\
\hline $\begin{array}{l}\text { skłonność do poszukiwania } \\
\text { pracy na terenie innego } \\
\text { województwa/miasta }\end{array}$ & 2,0 & 2,0 & 99,5 & 77,4 & 3,0295 & 0,00245 \\
\hline $\begin{array}{l}\text { skłonność do poszukiwania } \\
\text { pracy na terenie innego kraju }\end{array}$ & 3,0 & 2,0 & 104,4 & 73,7 & 4,11321 & 0,00004 \\
\hline $\begin{array}{l}\text { skłonność do poszukiwania } \\
\text { pracy na terenie innego } \\
\text { kontynentu }\end{array}$ & 4,0 & 2,0 & 109,4 & 69,8 & 5,27335 & 0,00000 \\
\hline $\begin{array}{l}\text { skłonność do zmiany pracy, } \\
\text { przyczyniającej się do rozwoju } \\
\text { kariery zawodowej }\end{array}$ & 3,0 & 3,0 & 86,3 & 87,6 & $-0,17458$ & 0,86141 \\
\hline
\end{tabular}

Źródło: opracowanie własne na podstawie wyników badań.

Wartości testu U Manna-Whitneya dotyczące skłonności badanych do poszukiwania pracy na terenie innej gminy $(2,29)$, innego województwa $(3,02)$, innego 
kraju $(4,11)$ czy kontynentu $(5,27)$ przy poziomie istotności $\alpha=0,05$ oraz odpowiednio uzyskane mediany i średnie (dla Polski i Portugalii) wskazują, że odpowiedzi są wyższe dla mieszkańców Polski w stosunku do mieszkańców Portugalii. Młodzi Polacy przejawiają mniejszą skłonność w porównaniu do Portugalczyków do mobilności przestrzennej. Interesujący jest natomiast fakt, że Polacy są bardziej skłonni $(-4,37)$ do zmiany własnych kwalifikacji zawodowych niż druga badana zbiorowość. Natomiast analiza pozostałego czynnika związanego z częstą zmianą pracy przyczyniającą się do rozwoju kariery zawodowej nie wykazała istotnych różnic.

Kolejna tabela prezentuje określenie stopnia ważności wybranych czynników zawodowych w przyszłej pracy respondentów (tab. 3).

Tabela 3. Ważność wybranych czynników zawodowych w przyszłej pracy respondentów

\begin{tabular}{|c|c|c|c|c|c|c|}
\hline & 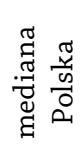 & 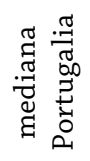 & 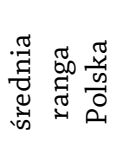 & 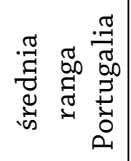 & 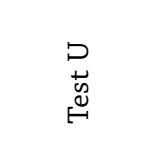 & 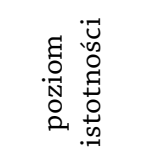 \\
\hline jasne reguły awansu & 2 & 2 & 72,5 & 98,1 & $-3,63463$ & 0,000278 \\
\hline wynagrodzenie & 2 & 2 & 76,4 & 95,1 & $-2,85029$ & 0,004368 \\
\hline $\begin{array}{l}\text { atmosfera wśród } \\
\text { pracowników }\end{array}$ & 1 & 2 & 77,2 & 94,5 & $-2,5456$ & 0,010909 \\
\hline $\begin{array}{l}\text { pozycja organizacji na } \\
\text { rynku }\end{array}$ & 2 & 2 & 100,6 & 76,6 & 3,32935 & 0,000871 \\
\hline $\begin{array}{l}\text { jasne kryteria oceny } \\
\text { pracowników }\end{array}$ & 2 & 2 & 80,1 & 92,3 & $-1,71319$ & 0,086679 \\
\hline motywatory pozapłacowe & 2 & 2 & 86,8 & 87,2 & $-0,05442$ & 0,956598 \\
\hline $\begin{array}{l}\text { możliwość rozwoju } \\
\text { zawodowego }\end{array}$ & 1 & 1 & 88,6 & 85,8 & 0,43284 & 0,665134 \\
\hline poczucie bezpieczeństwa & 2 & 2 & 88,8 & 85,7 & 0,45627 & 0,648194 \\
\hline $\begin{array}{l}\text { zachowanie równowagi } \\
\text { między pracą a życiem } \\
\text { rodzinnym }\end{array}$ & 1 & 1 & 90,9 & 84,0 & 1,06209 & 0,288195 \\
\hline $\begin{array}{l}\text { jakość kontaktów } \\
\text { z przełożonym }\end{array}$ & 2 & 2 & 91,4 & 83,7 & 1,13604 & 0,255942 \\
\hline
\end{tabular}

Źródło: opracowanie własne na podstawie wyników badań.

Test U Manna-Whitneya wykazał istotne zależności dla takich czynników jak: jasne reguły awansu $(-3,63)$, wynagrodzenie $(-2,85)$, atmosfera wśród pracowników $(-2,54)$ oraz pozycja organizacji na rynku $(3,32)$ - przy poziomie istotności 
$(\alpha=0,05)$. Biorąc pod uwagę otrzymane średnie i mediany można zauważyć, że wartości tych czynników (poza pozycją organizacji na rynku) są wyższe dla młodych osób mieszkających w Portugalii niż dla reprezentantów tego pokolenia w Polsce. Oznacza to, że dla młodych Polaków są one zdecydowanie ważniejsze i brane pod uwagę przy wyborze przyszłej pracy. Dla pozostałych czynników analiza nie wykazała istotnych różnic, a wynikające różnice w obliczeniach należy uznać jedynie za przypadkowe.

Zbadano również, w jakim stopniu na podejmowanie mobilności zawodowej i przestrzennej wpływają różne czynniki zawodowe w przyszłej pracy (tab. 4). Wartość współczynnika korelacji określono przy pomocy statystyki Rho Spearmana, przy progu istotności $\alpha=0,05$.

Tabela 4. Wpływ stopnia mobilności na wybrane czynniki zawodowe w przyszłej pracy w opinii respondentów

\begin{tabular}{|l|c|c|c|c|c|c|c|c|}
\hline \multicolumn{1}{|c|}{ zmienne } & \multicolumn{2}{|c|}{$\begin{array}{c}\text { skłonność } \\
\text { do zmiany } \\
\text { kwalifikacji } \\
\text { zawodowych }\end{array}$} & $\begin{array}{c}\text { skłonność do } \\
\text { poszukiwania } \\
\text { pracy na } \\
\text { terenie innego } \\
\text { województwa/ } \\
\text { miasta }\end{array}$ & $\begin{array}{c}\text { skłonność do } \\
\text { poszukiwania } \\
\text { pracy na terenie } \\
\text { innego kraju }\end{array}$ & $\begin{array}{c}\text { skłonność do } \\
\text { poszukiwania } \\
\text { pracy na } \\
\text { terenie innego } \\
\text { kontynentu }\end{array}$ \\
\cline { 2 - 10 } & PO & PRT & PO & PRT & PO & PRT & PO & PRT \\
\hline wynagrodzenie & 0,025 & $-0,239^{*}$ & $-0,018$ & $0,318^{*}$ & 0,092 & $-0,210^{*}$ & 0,031 & $-0,149$ \\
\hline $\begin{array}{l}\text { poczucie } \\
\text { bezpieczeństwa }\end{array}$ & 0,161 & $-0,078$ & $-0,053$ & $-0,070$ & 0,038 & $-0,186$ & $-0,009$ & $-0,225^{*}$ \\
\hline $\begin{array}{l}\text { atmosfera wśród } \\
\text { pracowników }\end{array}$ & 0,157 & $-0,005$ & 0,055 & 0,077 & 0,112 & 0,102 & 0,146 & 0,032 \\
\hline $\begin{array}{l}\text { jakość } \\
\text { kontaktów } \\
\text { z przełożonym }\end{array}$ & $0,325^{*}$ & 0,017 & $-0,033$ & 0,119 & 0,035 & 0,093 & 0,100 & 0,086 \\
\hline $\begin{array}{l}\text { pozycja } \\
\text { organizacji na } \\
\text { rynku }\end{array}$ & $-0,069$ & $-0,039$ & 0,156 & 0,021 & 0,206 & 0,059 & 0,134 & 0,017 \\
\hline $\begin{array}{l}\text { możliwość } \\
\text { rozwoju } \\
\text { zawodowego }\end{array}$ & 0,088 & 0,001 & 0,176 & $-0,001$ & $0,244^{*}$ & 0,178 & $0,282^{*}$ & 0,092 \\
\hline $\begin{array}{l}\text { motywatory } \\
\text { pozapłacowe }\end{array}$ & $-0,010$ & $-0,132$ & $0,298^{*}$ & $-0,068$ & $0,274^{*}$ & 0,073 & 0,201 & 0,110 \\
\hline $\begin{array}{l}\text { jasne kryteria } \\
\text { oceny } \\
\text { pracowników }\end{array}$ & 0,141 & $-0,060$ & 0,202 & $0,234^{*}$ & 0,158 & 0,158 & 0,119 & 0,135 \\
\hline
\end{tabular}




\begin{tabular}{|c|c|c|c|c|c|c|c|c|}
\hline \multirow[t]{2}{*}{ zmienne } & \multicolumn{2}{|c|}{$\begin{array}{c}\text { skłonność } \\
\text { do zmiany } \\
\text { kwalifikacji } \\
\text { zawodowych }\end{array}$} & \multicolumn{2}{|c|}{$\begin{array}{c}\text { skłonność do } \\
\text { poszukiwania } \\
\text { pracy na } \\
\text { terenie innego } \\
\text { województwa/ } \\
\text { miasta }\end{array}$} & \multicolumn{2}{|c|}{$\begin{array}{l}\text { skłonność do } \\
\text { poszukiwania } \\
\text { pracy na terenie } \\
\text { innego kraju }\end{array}$} & \multicolumn{2}{|c|}{$\begin{array}{c}\text { skłonność do } \\
\text { poszukiwania } \\
\text { pracy na } \\
\text { terenie innego } \\
\text { kontynentu }\end{array}$} \\
\hline & $\mathrm{PO}$ & PRT & $\mathrm{PO}$ & PRT & $\mathrm{PO}$ & PRT & $\mathrm{PO}$ & PRT \\
\hline $\begin{array}{l}\text { jasne reguły } \\
\text { awansu }\end{array}$ & 0,106 & $-0,042$ & 0,124 & 0,098 & 0,147 & 0,079 & 0,148 & 0,023 \\
\hline $\begin{array}{l}\text { zachowanie } \\
\text { równowagi } \\
\text { między pracą } \\
\text { a życiem } \\
\text { rodzinnym }\end{array}$ & $-0,018$ & $-0,152$ & $-0,002$ & $-0,041$ & $-0,018$ & 0,005 & $-0,015$ & $-0,051$ \\
\hline
\end{tabular}

${ }^{*} \mathrm{p}<0,05$

Po - Polska

PRT - Portugalia

Źródło: opracowanie własne na podstawie wyników badań.

Uzyskane wartości współczynnika korelacji Rho Spearmana wskazują, że im silniej młode osoby z Polski wykazują skłonność do pracy na terenie innego miasta, kraju czy kontynentu tym ważniejsze są dla nich: motywatory pozapłacowe (r Pearsona=0,298) oraz możliwość rozwoju zawodowego ( $r$ Pearsona=0,282). $\mathrm{Z}$ kolei dla Portugalczyków ważne jest wynagrodzenie (r Pearsona=0,318), ale dotyczy to tylko ich skłonności do pracy w innym mieście. Mniej ważne staje się ono $\mathrm{w}$ procesie podejmowania decyzji przy poszukiwaniu pracy za granicą ( $\mathrm{r}$ Pearsona $=-2,210$ ) oraz podczas decyzji odnośnie zmiany kwalifikacji zawodowych ( $r$ Pearsona $=-0,239)$. Na te zależności wskazują ujemne korelacje. Interesujące jest natomiast to, że dla młodych osób z Polski silna skłonność do zmiany kwalifikacji zawodowych koreluje z ważnością jakości kontaktów z przełożonym.

\section{Dyskusja wyników}

Biorąc pod uwagę uzyskane wyniki badań empirycznych można zauważyć, że młodych Portugalczyków charakteryzuje większa mobilność w porównaniu do Polaków. Uzasadnieniem tego wydaje się geograficzne położenie Portugalii, która już od wielu lat jest krajem masowych migracji (Peixoto, 2009). Oprócz tego już w 2012 roku Krajowy Instytut Pracy i Kształcenia Zawodowego (IEFP) ogłosił, że od stycznia do kwietnia z Portugalii wyjechało ponad 10 tys. bezrobotnych. Wśród 
wyjeżdżających przeważają niestety osoby młode. Tym samym, w porównaniu $\mathrm{z}$ analogicznym okresem poprzedniego roku, liczba udających się na emigrację Portugalczyków wzrosła o 42\%. Eksperci z Krajowego Instytutu Statystyki (INE) w Lizbonie wskazują jednak, że skala zjawiska może być większa i należy przyjąć, że ponad 100 obywateli Portugalii każdego dnia opuszcza swój kraj w poszukiwaniu pracy (Money pl, 2012a). Natomiast z ankiety przeprowadzonej przez Federację Akademicką Porto wśród studentów w całym kraju wynika, że 69\% ankietowanych ma zamiar wyjechać po studiach za granicę. W ogromnej większości przypadków powodem takiej decyzji jest szukanie bardziej atrakcyjnych warunków zatrudnienia. Badani podkreślają, że do pozostania w Portugalii zniechęcają ich przede wszystkich pogarszające się w wyniku kryzysu warunki socjoekonomiczne i wprowadzane przez rząd oszczędności i cięcia budżetowe (Money pl, 2012b). Dlatego młodzi Portugalczycy są bardziej skłonni do poszukiwania pracy poza swoim miejscem zamieszkania. Poza tym przebywając w Portugalii można zauważyć, że mieszkańcy tego kraju w większości posługują się swobodnie językiem angielskim, co niewątpliwie ułatwia im swobodne przemieszczanie się.

Natomiast młodzi Polacy są bardziej skłonni do zmiany kwalifikacji zawodowych niż Portugalczycy. Wynika to zapewne $z$ tego, że są oni bardziej świadomi zachodzących relacji pomiędzy zmianą własnych kwalifikacji zawodowych, a ich konkurencyjnością na rynku pracy. Zdają sobie sprawę, że współcześnie nie wystarczy już zaprzestać nauki po ukończeniu studiów, ale trzeba nieustannie się rozwijać poprzez różne formy kształcenia, takie jak: podyplomowe studia, kursy czy szkolenia. Wpisuje się to także w promowaną ideę uczenia się przez całe życie. Wydaje się, że pokolenie to jest bardziej skłonne do zmiany zawodu i kwalifikacji niż ich rówieśnicy w minionym wieku. Są zatem bardziej elastyczni i już w czasie studiów podejmują różne działania, chcąc zwiększyć swoje szanse na rynku pracy (Bednarska-Wnuk, 2012, s. 233). W tym zakresie Polacy lepiej prezentują się niż Portugalczycy, gdyż aż 29,9\% badanych jest już zatrudniona w oparciu o zróżnicowane umowy o pracę. Interesujący jest również uzyskany wynik w kontekście mobilności przestrzennej. Chociaż skłonność Polaków do poszukiwania pracy poza miejscem swojego zamieszkania jest coraz wyższa, zwłaszcza po akcesji Polski z Unią Europejską (Głodowska, 2011), to nadal w porównaniu z innymi krajami owa mobilność jest mała. Jak wskazuje Główny Urząd Statystyczny w Polsce saldo migracji w 2009 roku wyniosło -0,5 a np. wskaźnik ten dla Portugalii w analogicznym okresie wyniósł 1,4, w Szwecji (6,7), a dla Norwegii $(8,0)$ (Rocznik Statystyki Międzynarodowej, 2012, s. 98). Co zatem wpływa na tak niską mobilność przestrzenną Polaków? Wydaje się, że jest to skutek przyzwyczajeń kulturowych, chęci stabilizacji i poczucia bezpieczeństwa. W poprzednim systemie gospodarczym Polacy mieli łatwość podjęcia nowej pracy i hołdowano 
przede wszystkim zasadzie „praca w jednej organizacji przez całe życie”. Chociaż badani przejawiają skłonność do emigracji do innego miasta czy kraju, to jednak miałaby ona miejsce jedynie w obrębie granic Unii Europejskiej, najchętniej blisko kraju zamieszkania. Tym samym przejawiają mniejszą chęć do pracy na terenie innego kontynentu. Potwierdzają to badania przeprowadzone w 2013 roku na próbie badawczej - 1,5 tysiąca osób do 30 roku życia. Tylko $16 \%$ respondentów zdecydowałoby się na wyjazd za granicę, który przede wszystkim podyktowany byłby: brakiem pracy i pieniędzy. Nie związany byłby jednak z możliwością chęci rozwoju zawodowego (Raport Sedlak\&Sedlak, 2012). Z kolei jak wskazuje tabela 3 badani młodzi Polacy to właśnie możliwość rozwoju zawodowego (obok motywatorów pozapłacowych) wskazują jako główny motyw, skłaniający ich do mobilności przestrzennej. Interesujący jest natomiast uzyskany wynik odnośnie skłonności badanych do zmiany miejsca pracy (pracodawcy). Badani nie dostrzegają zatem zależności pomiędzy częstą zmianą miejsca pracy, a ich konkurencyjnością na rynku pracy. Przecież zmiana miejsca pracy może być okazją do nabywania nowych kwalifikacji, poprawy warunków pracy i realizacji nowych możliwości czy wyzwań zawodowych. Być może jest to związane z panującą opinią, że osoba, która ciągle zmienia pracę dla potencjalnego pracodawcy wydaje się być „skoczkiem” (tzw. jumper) czyli pracownikiem nieumiejącym przystosować się do środowiska organizacyjnego (Bednarska-Wnuk, 2012, s. 234). Z drugiej jednak strony jak wskazują badania firmy doradztwa personalnego IPK, osoby poniżej 25 roku życia zmieniają pracodawcę średnio co 14 miesięcy, a zakres obowiązków - prawie co rok. Jest to wynikiem cenienia sobie własnej niezależności i przywiązywania większej wagi do życia prywatnego niż zawodowego. Innym powodem ciągłego zmieniania pracy jest niedostosowanie do rzeczywistości wyobrażeń o pracy, jakie mają absolwenci szkół wyższych oraz rosnące tempo życia (Pawłowska-Salińska, 2012).

Natomiast biorąc pod uwagę znaczenie wybranych czynników zawodowych w przyszłej pracy respondentów należy uznać, że wszystkie one uzyskały niskie wartości mediany. Przy sformułowanym zaś założeniu w procesie badawczym (gdzie 1 - oznaczało zdecydowanie tak) świadczą one o tym, że wszystkie te czynniki są ważne w procesie decyzyjnym w kontekście podejmowania zatrudnienia przez młode osoby. Różnicując je można wyodrębnić dwa czynniki, które osiągnęły najlepsze wyniki w obu badanych zbiorowościach. Należą do nich: możliwości rozwoju zawodowego oraz zachowanie równowagi między życiem zawodowym a rodzinnym. Koresponduje to również z licznymi badaniami (Smith 2010; Cogin 2012; Andy 2008), które wskazują, że młode pokolenie należące do generacji Y bardziej ceni sobie niezależność, utrzymanie równowagi między pracą zawodową a życiem rodzinnym, mniej zaś jest zainteresowane tradycyjną ścieżką kariery. Choć młodzi ludzie zdają sobie sprawę z kryzysu na rynku pracy i rosnącego 
bezrobocia, to są skłonni obniżyć swoje wymagania jedynie co do treści pracy. Natomiast odnośnie wynagrodzeń, awansu, rozwoju czy zachowania równowagi work-life-balance mają zbyt wygórowane żądania. Takie postawy wobec pracy są charakterystyczne właśnie dla pokolenia Y. Przeciwnie niż poprzednie pokolenie, które w procesie pracy przejawiało przede wszystkim lojalność wobec organizacji oraz poświęcenie dla pracy kosztem życia rodzinnego.

\section{Zakończenie}

Reasumując należy zauważyć, że młodzi ludzie niezależnie czy mieszkają w Polsce, czy w Portugali przejawiają jednak dużą mobilność przestrzenną i zawodową. Wynika to z coraz większej ich świadomości odnośnie funkcjonowania na konkurencyjnym rynku pracy przy znacznych zasobach ludzkich. W tej sytuacji muszą charakteryzować się odpowiednim stopniem elastyczności w działaniu. Pozytywnym natomiast aspektem jest to, że zdają sobie $z$ tego sprawę i zamierzają szukać pracy w innym mieście czy kraju.

Wskazując na praktyczne rekomendacje przeprowadzonych badań należy podkreślić rolę mobilności w aspekcie kształtowania postaw młodych osób. Oprócz tego doceniając ich wysoki poziom mobilności, jeśli kraje nie chcą stracić młodych, dobrze wykształconych osób, powinny wypracować pewne mechanizmy służące poprawie ich dramatycznej sytuacji na współczesnym rynku pracy. Tym bardziej, że to właśnie ta grupa będzie w przyszłości decydować o losach swojego kraju, dlatego należy wprowadzać takie rozwiązania, aby młode osoby mogły wykorzystać w praktyce zdobytą wiedzę i rozwinąć równolegle swoje umiejętności, zwłaszcza w obliczu starzenia się populacji. Wśród proponowanych rozwiązań można wymienić:

- kształtowanie programów nauczania (łączenie wiedzy teoretycznej z wiedzą praktyczną) i dopasowanie ich do potrzeb rynku pracy,

- wprowadzenie obowiązkowych staży zawodowych podczas studiów, które umożliwią młodym osobom już na etapie nauki ich aktywizację zawodową,

- wprowadzenie zachęt (stypendiów) dla osób, które chciałyby powrócić do kraju,

- ułatwienia podatkowe dla młodych osób,

- ponoszenie przez pracodawców mniejszych kosztów pracy (na określony czas),

- wprowadzenie ułatwień dla młodych osób w zakresie podejmowania działalności gospodarczej,

- zapewnienie doradztwa zawodowego już na wczesnym etapie edukacji w celu kształtowania przyszłej ścieżki kariery oraz zmiany postaw w stosunku do przyszłych pracodawców. 
Podsumowując należy podkreślić, że uzyskane wyniki badań chociaż rozszerzają perspektywę dotyczącą funkcjonowania młodych osób na rynku pracy w Polsce i w Portugalii, to jednak trzeba wskazać na pewne występujące ograniczenia podczas badań empirycznych. Przede wszystkim problematyczny wydaje się dobór próby i jej nieprezentatywność. Należałoby zatem przeprowadzić pogłębione badania, charakteryzujące się reprezentatywnością i heterogenicznością badanej zbiorowości. Także badanie uwzględniło tylko wybrane obszary opisujące mobilność przestrzenną i zawodową. Powyższe ograniczenia mogą stać się jednak zachętą do podejmowania dalszych prac zmierzających dla lepszego poznania kształtowania się postaw mobilnych osób młodych. Taka dokonana diagnoza może również ukazać skalę problemów, z jakimi borykają się młode osoby na współczesnym asymetrycznym rynku pracy, bez względu na ich usytuowanie geograficzne.

\section{Bibliografia}

Andy, A. (2008), Young, gifted and hired, "People Management", Vol. 14, Issue 21.

Bednarska-Wnuk, I. (2013), Zachowania mobilne pracownika $w$ miejscu pracy - próba identyfikacji kluczowych determinant, w: M. Czajkowska, K. Januszkiewicz, M. Kołodziejczak, M. Zalewska-Turzyńska (red.), Uwarunkowania zachowań ludzi w organizacji, Acta Universitatis Lodziensis, Folia Oeconomica 282.

Bednarska-Wnuk, I. (2012), Mobilność jako czynnik przewagi konkurencyjnej wspótczesnego pracownika $Y-w$ opinii studentów Wydziatu Zarzq̨dzania UE, „Studia Ekonomiczne Regionu Łódzkiego", Wydanie Specjalne, Polskie Towarzystwo Ekonomiczne Oddział w Łodzi, Łódź.

Brzostek, D. (2008), Młodzi zmieniaja pracę jak rękawiczki, dostęp 15.05.2013, http:// gazetapraca.pl/gazetapraca/1,90442,5452820,Mlodzi_zmieniaja_prace_jak_rekawiczki.html

Cogin, J. (2012), Are generational differences in work values fact or fiction? Multi-country evidence and implications, "International Journal of Human Resource Management", Vol. 23, Issue 11.

Costa, H.A. (2012), From Europe as a model to Europe as austerity: the impact of the crisis on Portuguese trade unions 1, "Transfer: European Review of Labour and Research", Vol. 18, Issue 4.

Dias, J., Conceição Cerdeira, M. (2011), Collective Bargaining During the Crisis: The Portuguese Case, "Chinese Business Review", Vol. 10, No. 6.

Dimian, G.C., Dimian, M. (2011), Romania - Portugal: A Comparative Analysis of the Two Countries' Labour Markets, "Annals of the University of Oradea, Economic Science Series", Vol. 20, Issue 2. 
Eurostat (2014), dostęp 6.01.2014, z http://epp.eurostat.ec.europa.eu/statistics_ explained/index.php/Unemployment_and_beyond.

Głodowska, A. (2011), The Crisis impact on human capital formation in Poland, "Journal of Business Management", No 4.

Guyader, M. (2012), La crise de la zone euro peut elle faire surgir de nouvelles frontières en Europe centrale et orientale? "Eurolimes", Vol. 13.

Guillén, A. (2012), Europe: The Crisis Within a Crisis, "International Journal of Political Economy", Vol. 41, No. 3.

Houston, D. (2005), Employability, Skills Mismatch and Spatial Mismatch in Metropolitan Labour Markets, "Urban Studies”, Vol. 42, No. 2.

Istituto Nacional de Estatistica (2014). Statistics in Portugal, dostęp 6.01.2014, http:// www.ine.pt/xportal/xmain?xpid=INE\&xpgid=ine_main

Kronenberg, K., Carree, M. (2012), On the Move: Determinants of Job and Residential Mobility in Different Sectors, "Urban Studies", Vol. 49, No. 16.

Kryńska, E. (2001), Dylematy polskiego rynku pracy, Instytut Pracy i Polityki Społecznej, Warszawa.

Ng, W.H., Sorensen, K.L., Eby, L.T., Feldman, D.C. (2007), Determinants of job mobility: A theoretical integration and extension, "Journal of Occupational and Organizational Psychology", Vol. 80, Issue 3.

Nicholson, N., West M. (1988), Managerial Job Change: Men and Women in Transition, Cambridge University Press.

Money pl. (2012a), Kryzys $w$ Portugalii zmusza do emigracji zarobkowej, dostęp 15.05.2013, http://www.money.pl/gospodarka/wiadomosci/artykul/kryzys;w;po rtugalii;zmusza;do;emigracji;zarobkowej,245,0,1088757.html

Money pl. (2012b), Portugalia straci wykształconych? Planuja emigracje, dostęp 12.04.2013, http://www.money.pl/gospodarka/wiadomosci/artykul/portugalia;s traci;wyksztalconych;planuja;emigracje,58,0,1141818.html

Pawłowska-Salińska, K. (2012), Pracownicy przyszłości: skoczek i boomerang, dostęp 29.05.2013, http://gazetapraca.pl/gazetapraca/1,90443,12054917,Pracownicy_ przyszlosci__skoczeki_bumerang.html

Peixoto, J. (2009), New Migrations in Portugal: Labour Markets, Smuggling and Gender Segmentation, "International Migration", Vol. 47, Issue 3.

Raport Sedlak\&Sedlak (2012), Mobilni czy młodzi i wykształceni, dostęp 26.05.2013, http://www.rynekpracy.pl/pliki/dlaprasy/187.pdf

Samecki, P. (2011), The Eu Response To The Crisis and Recession: what has been done, what is missing, w: Koczor M., Tokarski P. (red.), The EU Economy Response to tke Crisis and Prospects for the New Decade, The Polish Institute of International Affairs, Warszawa.

Smith, K.T. (2010), Work-Life Balance Perspectives ofMarketing Professionals in Generation Y, “Marketing Services Quarterly”, Vol. 31, No. 4. 
Sienkiewicz, Ł. (2009), Elastyczność zawodowa Polaków jako determinant decyzji zatrudnieniowych, w: M. Juchnowicz, (red.), Postawy Polaków wobec pracy w zarządzaniu kapitałem ludzkim, Oficyna Wolters Kluwer, Kraków.

Sorokin, P. (2009), Ruchliwość społeczna, Wydawnictwo Instytutu Filozofii i Socjologii PAN, Warszawa.

Rocznik Statystyki Międzynarodowej 2012, dostęp 22.05.2013, http://www.stat.gov. $\mathrm{pl} / \mathrm{cps} / \mathrm{rde} / \mathrm{xbcr} / \mathrm{gus} / \mathrm{RS} \_r o c z n i k$ _stat_miedzynarodowy_2012.pdf

Wikipedia (2013), Kryzys finansowy od 2007 roku, dostęp 12.11.2013, z http://pl.wikipedia.org/wiki/Kryzys_finansowy_od_2007

\section{Summary}

\section{Mobility in Young People's Perception: Based on Example of Poland and Portugal}

The aftermath of the 2008 financial crisis resulted in many countries, including those from the European Union, struggling with adverse trends in labor markets. Their asymmetry makes more and more people unemployed, especially those under 25 years of age. These are the people most of all very well educated, highly skilled and qualified. In view of this situation, many young people decide to change their place of residence or occupation in order to better adjust to the labor market. The aim of this article is to identify the degree of adapting of the young to their professional life. The article includes a comparison of selected occupational factors in their future work on the example of two countries: Poland and Portugal.

Keywords: mobility, generation Y, labor market, Poland, Portugal.

\section{Резюме}

\section{Мобильность в восприятии молодых АюАей - на примере Помьши и Португалии}

Последствия финансового кризиса 2008 года привели к тому, что многие страны, в том числе Европейского Союза, борются с отрицательными тенденциями на рынке труда. Его асимметрия вызывает то, что все растет число безработных главным образом в возрасте до 25 лет. Это прежде всего очень хорошо образованные люди с 
высокими умениями и квалификацией. В связи с этой ситуацией многие молодые люди принимают решение об изменении места жительства или смене профессии с целью лучще приспособиться к требованиям рынка труда. Целью настоящей статьи является идентификация степении одобрения склонности молодых людей к профессиональной и территориальной мобильности. Проведено также сравнение выбранных профессиональных факторов в их будущей работе на примере двух стран: Польши и Португалии.

Ключевые слова: мобильность, поколение Y, рынок труда, Польша, Португалия.

\section{Dr Izabela Bednarska-Wnuk}

Adiunkt w Katedrze Zarządzania Uniwersytetu Łódzkiego. Wśród zainteresowań naukowych autorki znajduje się tematyka dotycząca zachowań organizacyjnych, w tym zachowań mobilnych oraz kapitału ludzkiego w organizacji. Kierowała dwoma projektami w ramach dotacji celowej dla Młodych Naukowców oraz była jednym z wykonawców 7 Programu Ramowego Unii Europejskiej w Zakresie Badań i Rozwoju Technologicznego, w obszarze międzynarodowej wymiany kadry naukowej (Project No. 295050, acronym FOLSPEC). Obecnie jest głównym wykonawcą projektu finansowanego przez Narodowe Centrum Nauki - „Wielowymiarowa Analiza Zachowań Organizacyjnych (WAZO). Metodyka i narzędzie pomiaru“. Opublikowała ponad 30 artykułów naukowych, jest współredaktorem dwóch książek oraz autorem publikacji opracowanej na podstawie rozprawy doktorskiej. 